\title{
Reseña. Jorge Arrate. Con viento a favor. Vol. I. Del frente popular a la Unidad Popular. LOM Ediciones, 2017.
}

En las últimas décadas, el retorno de la historia política ha permitido revalorizar en su dimensión histórica, las biografías y las autobiografías, como huellas o dispositivos para comprender la política en tanto actividad humana, con lo racional, ideológico y lo subjetivo. Las representaciones, imágenes, expectativas, identidades y culturas políticas, han ocupado un nivel central en las actuales investigaciones. La historia del siglo XX con sus catástrofes sociales y políticas, probablemente previsibles para algunos iluminados, llevó a descentrar las preguntas por las definiciones de aquello considerado parte de las disputas del campo político. En ese marco, las biografías, y en particular las biografías políticas, han servido para combinar planos de manera más armoniosa, quizás más cercanos a la posibilidad de comprensión de nuestro propio presente, en donde las ideologías parecen ser fluidas y las identidades múltiples.

Esta autobiografía no es un relato lineal, da saltos en el tiempo, retrocede, avanza y se intensifica. Desde antes de nacer, hasta el momento de escritura de la memoria. Con la dosis justa de teleología, la misma que poseen todos relatos que se narran desde el presente hacia el pasado, y en el que las distintas experiencias se ordenan lógica y subjetivamente, para dotar de sentido a una trayectoria de 
vida. Jorge se enuncia desde un tiempo y un lugar, nuestro presente. Un presente que ha sido construido por un conjunto de actores con conciencia de generación, en el que se entrecruzan los largos sesenta, la gesta épica de la Unidad Popular, el drama de la Dictadura cívico-militar y la transición a la democracia. En ese ordenamiento que tiene intensidades diferenciadas, Jorge se otorga el permiso de "poseer el tiempo presente, para retorcerlo, estirarlo y doblarlo".

En la autobiografía de Jorge Arrate, se disputa el origen de aquello que podemos nominar como nuestro tiempo, una temporalidad cuyos límites son parte del proceso político, con evaluaciones incluidas, de aquello que pudo ser y no fue, de aquello que fue y que podría no haber sido mejor y de aquello que irremediablemente fue así. ¿Dónde nace nuestro tiempo? ¿Cuáles son las claves de nuestro presente? De qué forma las disputas por esos "orígenes" también son disputas por el "futuro"? ¿Qué expectativas contemporáneas organizan la experiencia pasada y construyen como telón de fondo la posibilidad de la historia?

Este texto da forma a una experiencia que tiene como centralidad a "la política", cuya lógica narrativa se va tramando desde antes de su nacimiento, como nieto de feminista, literata, padre laico y radical, madre hiperpresente, hijo único, de la clase media de la primera mitad del siglo XX, politizado durante la adolescencia, que abrazó los idearios de izquierda, en el marco de lo significaron 2 y 3 de abril de 1957, las campañas del FRAP, el impacto de la Revolución Cubana, Harvard, China, Vietnam, disputas y debates de estudiantes previos a los procesos de Reforma, el gobierno de la Unidad Popular y el compromiso irrestricto con una causa de transformación revolucionariamente democrática.

El exilio, el retorno, los ministerios, las embajadas y la candidatura a presidente de la República. En el nacimiento de Arrate, su madre ya había sido advertida: "este niño será Presidente". Tal como expresa el autor: su vida, marcada también por derrotas, lo han constituido en un sujeto consecuente, que no ha buscado ni el dinero ni nada material, sólo mantener en alto las banderas simbólicas del laicismo, de la tolerancia, de la justicia social y la igualdad, propias 
de la izquierda del siglo XX. Esa es su historia, con todo lo real y lo ficcional que tienen estas construcciones.

Esta autobiografía es valiosa, también, no sólo porque retrata la experiencia de un actor importante de la clase política chilena, sino porque Arrate dispone de una tesis interpretativa de la historia de Chile. No cualquiera puede hacer de su vida un ejemplo de esa tesis, donde las experiencias individuales se convierten en "la evidencia", "el rastro", "la huella" de la historia de un país y en particular, de la historia de la izquierda.

La vida relatada en este texto, configura una tesis compuesta por: a) La constitución de la izquierda sesentista, desde el recorrido de quien partió en el radicalismo laico, republicano y reformista. b) De una izquierda que participó de la institucionalidad y que legitimó la vía democrática, muchas veces tensionada con la vía revolucionaria. c) De los procesos migratorios de mediados del siglo $\mathrm{XX}$, una familia que transita desde la $\mathrm{V}$ región a Santiago. d)De un pequeño colegio particular pagado a uno público y emblemático. e)De una clase media que creía en la movilidad social y la experimentó, con algunas precariedades propias del desarrollo económico y social basado en un modelo industrializador sustitutivo de importaciones.

Esta tesis le entrega un marco de significación al ideario político y simbólico, enarbolado por una nueva izquierda, aquellos jóvenes que marcados por la Revolución Cubana, hicieron del emblema de revolución una mixtura con los principios de la izquierda que representaba Allende. Los 1000 días de la Unidad Popular exceden con creces ese tiempo calendario, porque estructuran un tiempo narrativo que resalta lo "único", "intenso" y "raudo", que sólo podía traernos un mejor futuro, de cambios, de mayor igualdad y mayor justicia social.

Las dedicatorias con las que se inicia cada subtítulo, dan cuenta de los actores que también participaron de ese proceso. Los cuerpos de ese tiempo, que son a su vez un excelente recurso para hacer una especie de "árbol" de la izquierda chilena. De aquellos que merecen ser recordados y cuyo conjunto en el texto, son expresión de aquellos símbolos de "justicia social y proyecto 
revolucionario", que recuperan sentido en un país marcado por la desigualdad, la xenofobia, la precariedad, el sobreconsumo, el endeudamiento y una promesa incumplida de desarrollo económico y social.

Con la etiqueta de nueva izquierda, no me refiero a partidos políticos nacidos en los 60, sino que a una "manera de ser y estar en el mundo". La de numerosos sujetos que abrazaron esa causa, entre el fin de su adolescencia y el abrupto paso al ser adulto, justo cuando se iniciaba el proceso de transformación que encarnaba la Unidad Popular. Jorge trabajó con Allende (que estaba en los sesenta) cuando estaba por cumplir sus 30 años. Esa generación, se hizo adulta con una carga histórica que pocos experimentan y pueden reconocer. Ellos construyeron un relato épico. Esta biografía lo confirma. Muy lejos de mi generación, o la de los canguros y más aún de los millenials.

Jorge reflexiona:

Vivimos entonces tiempos especiales, lo que no ocurre con frecuencia, aunque en política los participantes nos habituamos a una retórica a menudo maximalista, carente a veces de los tonos grises o intermedios, en que todo tiende a ser considerado grave, crítico, decisivo, histórico, blanco o negro. Luego, cuando el momento pasa, la historia pone a muchos acontecimientos en su sitio como modestos recuerdos sin profundidad o proyección. Pero los sesenta expresaron un vuelco cultural, nada permaneció intocado y ciertos hechos, como la revolución en Cuba y su desarrollo, marcaron la época. (143)

Así, socialistas, comunistas, mapucistas, izquierda cristiana, radicales de izquierda y miristas, experimentaron la época con una intensidad pocas veces distinguible en la historia de Chile. Fervientes creyentes en que la realidad social se podía transformar y que dependía de ellos, y su compromiso, para que ese cambio se produjera. Una izquierda con formación universitaria, que amplió las bases obreristas y de empleados que tradicionalmente formaron el bastión 
electoral de la misma y que dispuso de categorías, conceptos, además de teorías, para dar sentido nuevo a las prácticas parlamentarias, la revolución e incluso la violencia política, que han cruzado a la izquierda como gran fuente de identidad y de propuestas políticas.

La biografía también nos permite comprender un itinerario. La trayectoria académica de Arrate es un ejemplo de la constitución de ese grupo político intelectual que forma parte de la elite de la izquierda, nacional e internacional. Del Instituto Nacional pasó a la Universidad de Chile, a la importante Escuela de Derecho. Del trabajo de abogado tinterillo -en la oficina que le permitió ocupar Julio Stuardo, quien a su vez se la arrendaba a la mamá de Ricardo lagos-, a los estudios de posgrado en Escolatina, y de ahí a Harvard. La economía conquistó su alma. Disputó con la teoría neoclásica -en la que fue formado-, y participó de una heterodoxa teoría que combinó algunos elementos del marxismo con el neoinstitucionalismo. Heterodoxia que estuvo presente en las mismas políticas económicas de la Unidad Popular y que al menos, nos permiten cuestionar el reduccionismo con el que se ha analizado el proyecto económico que lideró Allende.

Con viento a favor no es una metáfora de tranquilidad, de navegación segura, con velocidad crucero. Jorge narra su historia en el ojo del huracán. Los hechos trascendentales de su vida, los nombres más importantes, son también los hechos y nombre de la historia de la izquierda chilena. 2 de abril y Jorge está en las afueras del Instituto Nacional. 1970 Jorge regresa desde Harvard para formar parte del proceso revolucionario. Tuvo la audacia de decirle a Allende que no podía asumir funciones de consejero, porque tenía el compromiso de dirigir la Instituto de Economía de la Universidad de Chile. Sin embargo a pesar de ese “no", dirigió la estatización de Quimantú, el proceso de nacionalización del cobre a través de la vicepresidencia ejecutiva de Codelco y tuvo un corto, pero importante rol como ministro interino de Minería. Visitó China, Zaire, estuvo con Miterrand y leyó la propuesta de Lelio Basso antes de que el eurocomunismo siquiera fuera una arena conocida para la izquierda socialista chilena. Antes de 
que su rostro fuera uno de los más reconocidos del Proceso de Renovación socialista. Fue Arrate el que pidió que guardaran la cámara con que el periodista francés grabó el tanquetazo del 29 de junio de 1973. Ese acto permitió disponer de imágenes de valor histórico incalculable. Pocos, muy pocos, deben saber (hasta ahora), que ese tesoro se guardó gracias a una decisión que emergió desde las ubicaciones de Codelco. Estar en el momento preciso, construir los hechos que nos permiten contarnos. Esta biografía da cuenta del poder de los relatos en la construcción de las identidades socio políticas.

Con viento a favor sea quizás la mejor metáfora de la creencia en que las "cosas" mejorarían, no sólo por voluntad, sino que también por justicia. Sin embargo, ese viento a favor se narra también con ráfagas que hacen tambalear la dirección y conducción del barco. Ráfagas que se convierten en tornados hacia marzo de 1973.

Arrate estuvo en el barco más complejo de la UP. Aquel que buscó transformar la economía con la institucionalidad vigente. Codelco y la batalla de la producción, estructuran la parte más dinámica del relato. Su lectura nos envuelve con una intensidad maravillosa. Creo que es uno de los mejores relatos que he leído sobre este proceso económico y social, uno que logra dar cuenta de las dificultades y los aciertos, pero sobre todo, uno que permite situarse en la vorágine de un tiempo vértice. El Paro del Teniente, la huelga en Chuquicamata, las asambleas con los sindicatos, el desabastecimiento, el acaparamiento, la intervención norteamericana, la derecha golpista, todo enmarañado en una interpretación que, si bien es conocida, no había logrado ser transmitida con el grado de vividez que lo hace Arrate.

Los áridos relatos sobre los aciertos y desaciertos de la política económica de la UP, se vuelven coloridos y amenos, en esta autobiografía. "La economía no se hace en una probeta", nos advierte Arrate. Se hace con fuerza de gravedad y roce. No funciona con modelos, porque hay multiplicidad de factores que inciden, a la postre, en los resultados finales. Este libro es un aporte fundamental para 
comprender la batalla de la producción y la nacionalización del cobre, con rostros y cuerpos humanos.

Otra novedad aparece en este texto. Algo que hasta hace poco, era bastión de un sector marginal de la izquierda chilena. La problemática de la violencia. Desde las páginas 396 hasta la 401, Arrate se hace cargo de un tema espinudo, pocas veces reconocido y tratado. ¿Se lo imaginan con una pistola? i"A la violencia reaccionaria respondemos con violencia revolucionaria"!. Miguel Enríquez y un barretín con armas. Entrenamiento militar. A medias. A tientas. Altamirano y Allende, un postre de coco real traído desde Cuba. Pinceladas, imágenes que guardé de la lectura. No avanzo más, porque me imagino que lo que aquí quedó esbozado se desarrollará con mucho más detalle en el tomo II. Al menos eso espero.

En la página 379, Arrate consigna:

Es posible que habitar el ojo de una tempestad profundice el tiempo y que cada momento adquiera una densidad sin igual y por eso los casi tres años de la Unidad Popular hoy me parezcan quince o veinte o veinticinco. Varias avalanchas simultáneas de acontecimientos yuxtapuestos, ligados entre si, chocaban, se enhebraban, se fundían y hacían chisporrotear sus contradicciones. Mirábamos con los cristales de la razón y la emoción, muchas veces encontrados, esa tensa amalgama de hechos políticos. Un torbellino era eje de nuestra vida. 
Pero para terminar quiero insistir que la vida de Jorge es también la vida de una generación, de proyectos, de sueños, de ideas y símbolos. Muchos de los cuales algunos compartimos, con las modificaciones, transformaciones y mutaciones que seguro vendrán en su segundo volumen. Su autobiografía se confunde con los relatos históricos. O al revés, la historia es el eje de su relato. Es imposible e inútil desentrañarlo. Así son las narrativas políticas y más en particular, de las elites.

$(\mathrm{cc}) \mathrm{EY}$ ULLS D-Senke
New articles in this journal are licensed under a Creative Commons Attribution 4.0 United States License.

This site is published by the University Library System, University of Pittsburgh as part of its D-Scribe Digital Publishing Program and is cosponsored by the University of Pittsburgh Press. 